\title{
ANALISIS POTENSI DAN PROSPEK PENGEMBANGAN INDUSTRI KECIL DI KOTA PEMATANGSIANTAR
}

\author{
J ef Rudiantho Saragih
}

\begin{abstract}
The research aim is to analyze the potential and development prospects of small industries in Pematangsiantar. The potential of small industry determined by production value, meanwhile the prospect of development depend on three variables that influenced the value of product, such as: production capacity, investment, and labor quantity. Data analyzed by shift-share analysis and multiple regression model. Research took place on August to November 2002. Based on production value, the result of research points out that most of small industries have a potential to develop, namely: printing and publishing services, moulding and building material component, tea processing, plastic packaging, chemistries, fish processing and preservation, chips made from several materials, household equipments, food made from peanut processing, and coffee processing. In general, several small industries have prospect to be developed by enhancing the capacity of production, investment, quantity and skill of the labor, and relevant government policy.
\end{abstract}

Keywords: small industry, potential, prospect

\section{PENDAhUluan}

Perkembangan industri kecil memiliki peranan yang sangat penting dalam pembangunan ekonomi Indonesia, terutama karena empat hal (Sirait, 1994). Pertama, proses produksi pada industri kecil sifatnya lebih padat karya. Oleh karena itu, perkembangannya menjadi salah satu instrumen kebijakan pemerintah yang bisa dianggap efektif untuk mengatasi pengangguran dan kemiskinan. Kedua, lokasi industri kecil adalah tersebar, yang berarti pembentukan dan distribusi pendapatan sangat tergantung pada perkembangan industri kecil. Perkembangan industri kecil akan membantu usaha-usaha pemerintah dalam mengurangi kesenjangan pendapatan atau pembangunan antar wilayah. Ketiga, proses produksi pada industri kecil sifatnya sangat intensif dalam pemakaian sumber alam lokal atau bahan bakar yang bisa dibuat di dalam negeri. Karenanya, pertumbuhan industri kecil tidak terlalu terpengaruh dampak negatif dari transaksi berjalan dan neraca pembayaran Indonesia, sebagaimana halnya industri menengah dan besar. Keempat, perkembangan industri kecil bisa mendukung usaha pemerintah untuk meningkatkan ekspor nonmigas.

Secara umum, industri kecil menghadapi berbagai kendala, terutama: (1) keterbatasan modal, (2) keterbatasan tenaga profesional, (3) kurangnya organisasi dan jaringan pemasaran, dan (4) proses produksi dan kualitas produk yang belum optimal (Tambunan,1994). Dengan demikian, tujuan pengembangan industri kecil bisa meliputi: (1) peningkatan pangsa pasar (market share) tingkat lokal, domestik, maupun ekspor, dan (2) peningkatan kemampuan daya saing, melalui efisiensi usaha, peningkatan kualitas produk, dan jaringan pemasaran (Subiakto, 1994).

Beranjak dari permasalahan tersebut dan dikaitkan denga tujuannya, maka strategi pengembangan industri kecil didasarkan pada kebijakan yang berbasis peningkatan kualitas sumberdaya manusia. Strategi umum yang dapat ditempuh adalah: (1) Pemanfaatan dan penciptaan peluang usaha serta peningkatan akses dan pangsa pasar, 
(2) Meningkatkan kemampuan pemupukan modal secara swadaya, (3) Meningkatkan penguasaan teknologi, (4) Meningkatkan kemampuan organisasi dan manajemen. Strategi ini dapat ditempuh melalui pelatihan, pameran, studi banding, dan lomba, (5) M eningkatan promosi, dan (6) M eningkatkan kemitraan dan keterkaitan usaha (Subiakto, 1994).

Kerangka berpikir itu sepertinya mendorong Pemerintah Kota Pematangsiantar menegaskan akan pentingnya pengembangan industri kecil sehingga menjadi substansi yang penting dalam dokumen perencanaan daerah, yaitu Program Pembangunan Daerah (Propeda) dan Rencana Strategis (Renstra), antara lain: (1) Pengembangan industri kecil berbasis pertanian lokal dengan pendekatan sistem agribisnis, (2) Meningkatkan pembinaan dan penyuluhan bagi industri kecil dan industri rumah tangga, dan (3) Mengidentifikasi sektor dan produk unggulan lokal sebagai bisnis inti untuk mendapat prioritas pengembangan.

Penelitian ini bertujuan untuk melakukan identifikasi potensi dan prospek pengembangan industri kecil di Kota Pematangsiantar. Hasil penelitian diharapkan bermanfaat sebagai bahan masukan dan informasi bagi Pemerintah Kota Pematangsiantar dalam menyusun perencanaan dan prioritas pengembangan industri kecil.

\section{KERANGKA PEMIKIRAN}

\subsection{Potensi Industri Kecil dan Rumah Tangga}

Potensi industri kecil di suatu wilayah tidak hanya ditentukan oleh sumber-sumber alam yang ada, tetapi juga oleh pengetahuan/ keterampilan yang dimiliki oleh penduduk. Perkembangan industri kecil di suatu wilayah tidak selalu berarti bahwa wilayah tersebut memiliki bahan baku yang berlimpah (endowment resources), tetapi lebih merupakan suatu kegiatan tradisional yang menggambarkan adanya suatu traditional skill yang dimiliki penduduknya.

Industri kecil dikenal dalam kehidupan masyarakat karena akar sejarahnya yang panjang serta terkait erat dengan tradisi dan jalur kehidupan sejumlah besar dari sektor ekonomi kerakyatan. Ini berarti industri kecil bukan sekedar bagian dari industri yang dapat diukur nilai materialnya semata-mata. Dengan demikian, pengembangan industri kecil harus mempertimbangkan sekurang-kurangnya tiga aspek utama, yaitu:

(1) Indutri kecil adalah subsektor yang menampung kehidupan dan tradisi budaya dari sejumlah besar anggota masyarakat.

(2) Industri kecil adalah bagian dari sarana penciptaan kesempatan kerja dan pengembangan keativitas bagi angkatan kerja, yang umumnya memiliki tingkat pendidikan formal yang tidak memadai bagi penyerapan tenaga kerja di sektor modern.

(3) Industri kecil adalah sarana distribusi kesempatan berusaha dan pendapatan yang lebih menjamin perwujudan pemerataan pembangunan dan hasil-hasilnya (SES, 1988 dalam Swasono, 1993)

\subsection{Kendala Pengembangan Industri Kecil}

Masalah utama yang dihadapi oleh industri kecil di suatu wilayah pada umumnya adalah: modal, pemasaran, bahan baku, tenaga kerja/ ahli, teknologi, manajemen dan organisasi. Berbagai studi menunjukkan bahwa kredit atau modal yang terbatas merupakan masalah utama bagi industri kecil. Industri kecil menghasilkan jenis barang yang mengandung nilai elastisitas pendapatan terhadap permintaan yang lebih besar 
dari nol. Ini berarti permintaan terhadap barang-barang buatan industri kecil akan meningkat dengan meningkatnya pendapatan per kapita penduduk di suatu wilayah. Berbagai masalah tesebut di atas, pada hakekatnya tidak berdiri sendiri, tetapi saling terkait satu dengan yang lain. Kekurangan modal menyebabkan kesulitan menyediakan sarana dan prasarana. Sementara kekurangan modal dapat disebabkan oleh permintaan rendah akibat kualitas produk yang rendah. Kualitas rendah disebabkan oleh tenaga kerja kurang terampil, teknologi terbatas, persaingan dengan industri menengah-besar, persaingan dengan produk impor, dan masalah manajemen (lihat Gambar I).

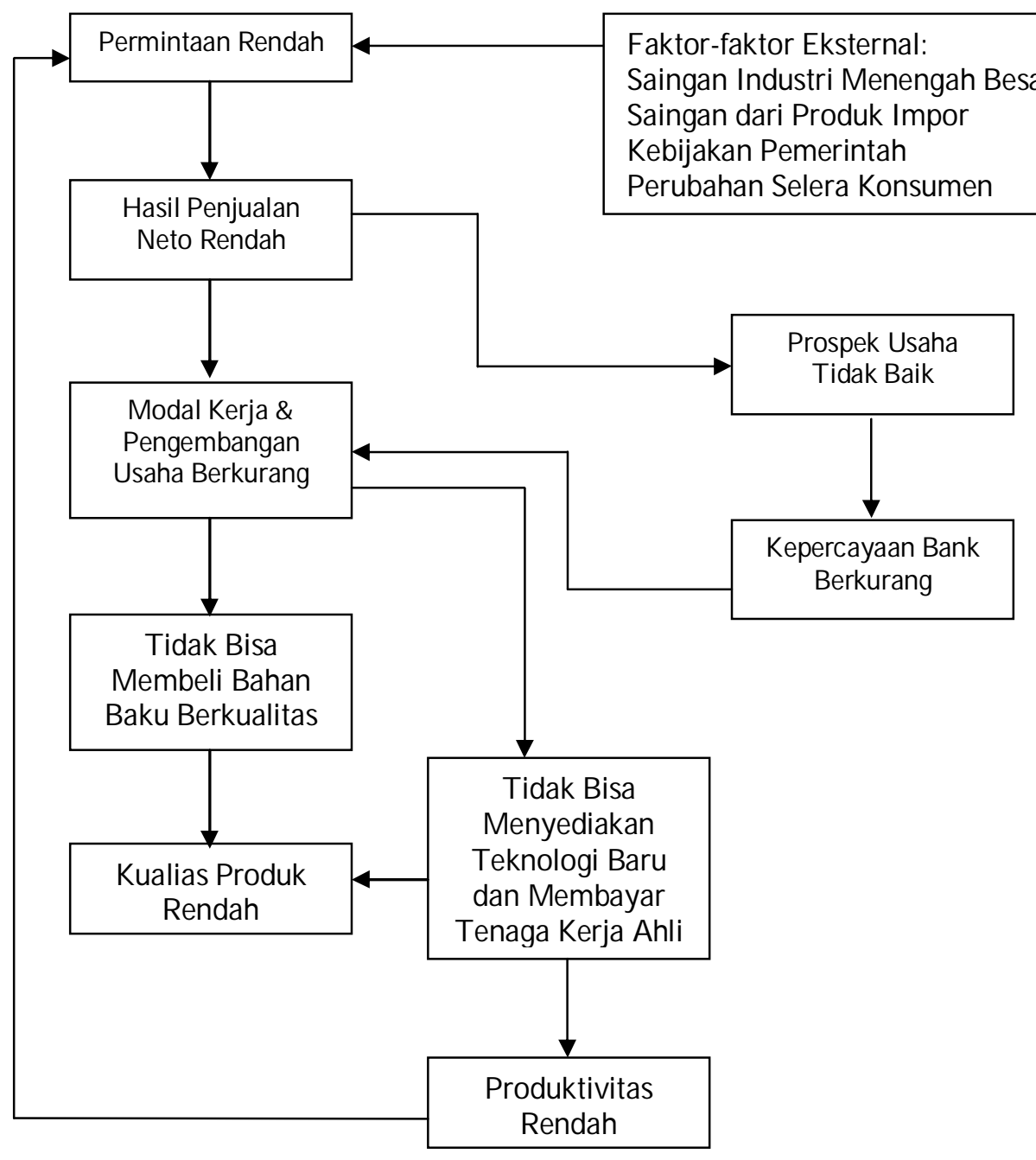

Sumber: Tambunan (1994)

Gambar 1. Keterkaitan Masalah Utama yang Dihadapi oleh Industri Kecil

\section{METODOLOGI PENELITIAN}

\subsection{Batasan Operasional}

Industri. Industri adalah kegiatan ekonomi yang mengolah bahan mentah, bahan baku, barang setengah jadi, dan/ atau barang jadi menjadi barang dengan nilai yang lebih 
tinggi untuk penggunaannya, termasuk kegiatan rancang bangun dan perekayasaan industri. J enis industri adalah bagian suatu cabang industri yang mempunyai ciri khusus yang sama dan/atau hasilnya bersifat akhir dalam proses produksi. Industri Kecil. Industri kecil adalah industri dengan investasi di atas Rp 5 juta s/ d Rp 200 juta, tidak termasuk lahan dan aset. Potensi dan Prospek Pengembangan. J enis industri kecil berpotensi ditentukan berdasarkan nilai produksi masing-masing jenis industri. Prospek pengembangan masing-masing jenis industri berpotensi ditentukan dari peranan tiga variabel yang mempengaruhi nilai produksi, yaiu kapasitas produksi, investasi, dan iumlah tenaga kerja.

\subsection{Tempat dan Waktu Penelitian}

Penelitian dilaksanakan di Kota Pematangsiantar pada bulan Agustus sampai dengan Nopember 2002.

\subsection{Data dan Sumber Data}

Data utama yang diperlukan adalah Produk Domestik Regional Bruto (PDRB), nilai produksi masing-masing jenis industri kecil, kapasitas produksi, jumlah investasi, dan jumlah tenaga kerja. Data PDRB bersumber dari BPS, data industri kecil bersumber dari Dinas Perindustrian dan Perdagangan.

\subsection{Metode Analisis Data}

a. Analisis Shift-Share

Pertumbuhan sektor industri akan diuraikan menjadi komponen shift dan share. Komponen national share $(\mathrm{N})$ dapat menjadi kriteria bagi daerah untuk mengukur penyimpangan (perbedaan) sektor industri dalam pertambahan penyerapan tenaga kerja (employment) atau PDRB dalam penyerapan tenaga kerja daerah atau penciptaan PDRB. Ini berarti pertumbuhan penyerapan tenaga kerja atau kontribusi PDRB antara sektor industri dengan sektor-sektor lain, sama besarnya.

Koinponen shift menunjukkan penyimpangan dari national share. Penyimpangan akan positif bila sektor industri bertumbuh dengan baik dan sebaliknya akan negatif jika merosot. Komponen shift dapat dibagi menjadi proportionality shift component (P) dan differential shift component (D).

Proportionality shift untuk mengetahui pengaruh unsur-unsur dari luar (ekstern) dan differential shift untuk mengetahui pengaruh dari faktor-faktor dalam (intern) sektor industri.

Analisis shift-share dapat dinotasikan sebagai berikut:

$$
\begin{aligned}
G j & =E j_{t}-E j_{0} \\
& =(N j+P j+D j) \\
N j & =E j_{0}\left(E_{t} / E_{0}\right)-E j_{0} \\
(P+D)_{j} & =E j_{t}-\left(E_{t} / E_{0}\right) E j_{0} \\
& =(G j-N j) \\
P j & \left.=\sum i\left[E j_{t} / E j_{0}\right)-\left(E_{t} / E_{0}\right)\right] E i_{0} \\
D j & =\sum i\left[\left(E j_{t}-\left(E i_{t} / E i_{0}\right) E i_{0}\right]\right. \\
& =(P+D) j-(P j)
\end{aligned}
$$




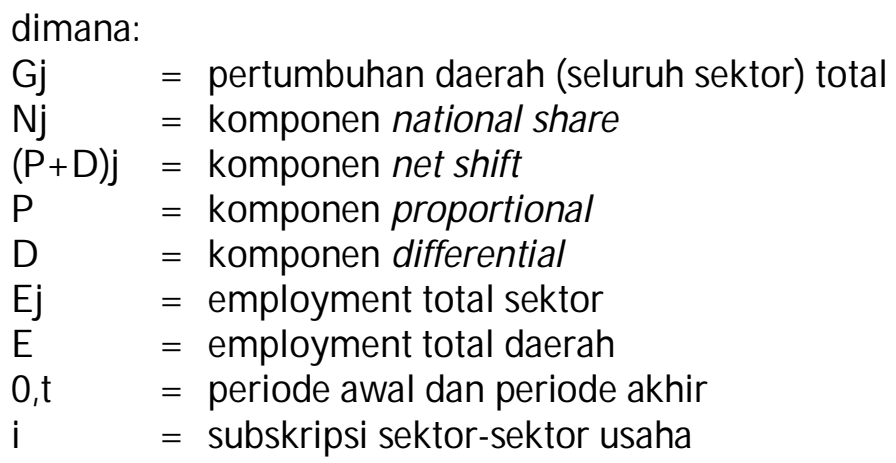

b. Analisis Regresi Majemuk

Untuk menganalisis prospek pengembangan masing-masing jenis industri berpotensi, digunakan analisis regresi majemuk (diolah dengan software MicroStat), dengan model:

$$
\begin{array}{ll}
Y=\alpha+\beta_{1} \text { Kpsts }+\beta_{2} \text { Invest }+\beta_{3} \text { TK } \\
\begin{array}{ll}
\text { dimana: } & \\
Y & =\text { nilai produksi (Rp) } \\
\text { Kpsts } & =\text { kapasitas produksi (satuan volume) } \\
\text { Invest } & =\text { investasi (Rp) } \\
\text { TK } & =\text { tenaga kerja (orang) } \\
\alpha & =\text { konstanta (intersep) } \\
\beta_{1}, \beta_{2}, \beta_{3} & =\text { koefisien regresi }
\end{array}
\end{array}
$$

Untuk mengetahui dapat tidaknya persamaan digunakan untuk menduga kapasitas produksi, investasi dan penyerapan tenaga kerja dilakukan uji-F dan selanjutnya untuk mengetahui keberartian pengaruh masing-masing variabel dilakukan uji t.

\section{HASIL PENELITIAN DAN PEMBAHASAN}

\subsection{Kontribusi Kota Pematangsiantar dalam Perekonomian Sumatera Utara}

Secara keseluruhan, perekonomian Provinsi Sumatera Utara didominasi oleh sektor pertanian: akan tetapi untuk daerah kota, lebih berkembang lapangan usaha sekunder dan tersier. Sebagai daerah kota, Pematangsiantar mempunyai peranan yang tidak terlalu besar dalam pembentukan PDRB Provinsi Sumatera Utara. Pada Tabel I dapat dilihat secara garis besar perekonomian (PDRB) Kota Pematangsiantar dan peranannya dalam perekonomian Sumatera Utara.

Berdasarkan data tersebut, terlihat bahwa kontribusi perekonomian Kota Pematangsiantar dalam perekonomian Provinsi Sumatera Utara hanya $2,77 \%$. Yang paling penting diperhatikan, ternyata bahwa peranan dari empat lapangan usaha terpilih cukup menonjol, khususnya lapangan usaha industri.

J ika dilihat berdasarkan penggolongan industri, ternyata kelompok industri besarsedang memberi kontribusi $4,72 \%$ dan industri kecil dan rumah tangga sebesar 7,19\%. Artinya, di antara sembilan lapangan usaha yang berkembang di Kota Pematangsiantar, ternyata lapangan usaha industri khususnya industri kecil dan rumah tangga, mempunyai peranan tertinggi dalam membangun perekonomian yang lebih besar (Sumatera U tara). 
Tabel I. Peran Lapangan U saha Terpilih Kota Pematangsiantar dalam PDRB Provinsi Sumatera Utara Tahun 2000 (Rp J uta)

\begin{tabular}{clrrr}
\hline No. & Lapangan Usaha & Sumut (A) & P. Siantar (a) & Kontribusi (\%), a/ A \\
\hline 1 & Industri : & & & \\
& Besar dan Sedang & 4.491 .186 & 212.144 & 4,72 \\
& Kecil dan Rumah Tangga & 471.329 & 33.871 & 7,19 \\
2 & Perdagangan, Hotel dan & 4.145 .650 & 114.560 & 2,76 \\
& Restoran & & & \\
3 & Pengangkutan dan & 1.917 .739 & 94.483 & 4,93 \\
& Komunikasi & & & 3,91 \\
4 & Jasa-jasa & 1.767 .182 & 69.092 & 1,17 \\
5 & Lainnya & 18.555 .638 & t23.629 & 2,77 \\
\hline
\end{tabular}

Sumber: BPS Sumut, 2001 (diolah)

\subsection{Analisis Shift-Share}

Berdasarkan pertumbuhan nilai PDRB Kota Pematangsiantar dan Provinsi Sumatera Utara tahun 1996-2000, ternyata bahwa secara umum, laju pertumbuhan perekonomian Kota Pematangsiantar tidak mengikuti (tidak proporsional) pertumbuhan Provinsi Sumatera Utara. Perekonomian Kota Pematangsiantar mengalami penyimpangan ke arah positif, yang menunjukkan laju pertumbuhan yang lebih besar. Selama periode tahun 1996-2000, perekonomian Kota Pematangsiantar bertumbuh rata-rata 2,61\% per tahun, sedangkan Provinsi Sumatera Utara hanya 2,10\% per tahun.

Tabel 2. Distribusi Penyimpangan Pertumbuhan Perekonomian Kota Pematangsiantar dari Sumatera U tara Tahun 1996-2000

\begin{tabular}{clrrr}
\hline No. & Lapangan Usaha & $\begin{array}{c}\text { Proportional } \\
\text { shift }\end{array}$ & $\begin{array}{c}\text { Differential } \\
\text { shift }\end{array}$ & \multicolumn{1}{c}{ Net shift } \\
\hline 1 & Industri Besar dan Sedang & $-14.093,18$ & 14.760 .48 & 667,30 \\
2 & Industri Kecil dan Rumah Tangga & $2.836,82$ & $-4.652,03$ & $-1.815,21$ \\
3 & Perdagangan Hotel dan Restoran & $-4.884,71$ & $19.493,23$ & $14.608,52$ \\
4 & Pengangkutan dan Komunikasi & $-8.625,83$ & $8.929,31$ & 303,48 \\
5 & Keuangan, Persewaan dan J asa & $-11.307,52$ & $6.537,79$ & $-4.769,73$ \\
& Perusahaan & $-2.001,43$ & $9.554,64$ & $7.553,21$ \\
6 & Jasa-jasa & 5.524 .53 & $-8.802,53$ & $-3.278,00$ \\
7 & Lainnya & $25.870,80$ & $47.347,51$ & \\
& Jumlah & & $21.476,71$ \\
\hline
\end{tabular}

Sumber: Biro Pusat Statistik Sumatera Utara, 2001

Nilai aktual pertambahan PDRB Kota Pematangsiantar pada periode tahun 19962000 adalah sebesar $\mathrm{Rp}$ 67.697.600.000. Seandainya perekonomian Kota Pematangsiantar bertumbuh mengikuti pertumbuhan perekonomian Provinsi Sumatera Utara (rata-rata 2,10\% per tahun), besarnya pertambahan nilai PDRB Kota Pematangsiantar adalah $\mathrm{Rp} 46.220 .890 .000$. Nilai ini disebut sebagai national share, 
yang secara teoritis dianggap sebagai pertumbuhan yang diakibatkan (determined) wilayah yang lebih besar (Provinsi Sumatera Utara).

Dengan demikian terdapat selisih positif yang cukup besar, yaitu Rp 21.476.710.000. Selisih ini dianggap sebagai penyimpangan atau lebih dikenal dengan istilah net shift. Penyimpangan ini (net shift) disebabkan pertumbuhan yang proporsional (proportional shift) dengan lapangan usaha sejenis dan penyimpangan (differential shift) yang diakibatkan pengaruh keunggulan lokasi, untuk seluruh lapangan usaha (Tabel 2).

\subsection{Potensi dan Prospek Pengembangan Industri Kecil}

Untuk menguraikan potensi dan prospek pengembangan industri kecil digunakan analisis regresi majemuk, dengan menggunakan data nilai produksi, kapasitas produksi, nilai investasi dan jumlah tenag a kerja. Data yang dianalisis adalah data tahun 2001. Hasil analisis regresi disajikan pada Tabel 3.

Tabel 3. Hasil Analisis Regresi Potensi dan Prospek Pengembangan Industri Kecil

\begin{tabular}{|c|c|c|c|c|c|c|c|c|}
\hline \multirow{2}{*}{ No. } & \multirow{2}{*}{$\begin{array}{l}\text { Jenis Industri } \\
\text { Kecil }\end{array}$} & \multirow{2}{*}{$\begin{array}{l}\text { Rerata } \\
\text { Nilai } \\
\text { Produksi }\end{array}$} & \multirow{2}{*}{ Intersep } & \multicolumn{3}{|c|}{ Koefisien Regresi } & \multirow{2}{*}{$\mathrm{R}^{2}$} & \multirow{2}{*}{ F-ratio } \\
\hline & & & & Kpsts & Invest & TK & & \\
\hline 1 & $\begin{array}{l}\text { Pengolahan/ pe- } \\
\text { ngawetan ikan }\end{array}$ & 160,8 & 417,64 & $\begin{array}{c}0,75 \\
(7,08)^{* *}\end{array}$ & $\begin{array}{c}0,31 \\
(2,17)^{* *}\end{array}$ & $\begin{array}{c}-0,54 \\
(-11,8)^{* * *}\end{array}$ & 0,99 & $239,91^{* * *}$ \\
\hline 2 & Roti & 91,51 & $-33,74$ & $\begin{array}{c}0,36 \\
(1,10)\end{array}$ & $\begin{array}{c}1,61 \\
(5,45)^{* * *}\end{array}$ & $\begin{array}{l}-0,51 \\
(-0,43) \\
\end{array}$ & 0,85 & $12,25^{* * *}$ \\
\hline 3 & Pengolahan teh & 387,34 & $-0,22$ & $\begin{array}{c}-3,74 \\
(-8,49)^{* *} \\
\end{array}$ & $\begin{array}{c}5,45 \\
(31,43)^{* * *} \\
\end{array}$ & $\begin{array}{l}-2,36 \\
(-2,00) \\
\end{array}$ & 0,99 & $448,68 * * *$ \\
\hline 4 & Pengolahan kopi & 102,53 & $-40,96$ & $\begin{array}{c}0,93 \\
(7,16)^{* * *}\end{array}$ & $\begin{array}{c}0,18 \\
(1,15) \\
\end{array}$ & $\begin{array}{c}2,33 \\
(3,11)^{* *}\end{array}$ & 0,99 & $102,26 * * *$ \\
\hline 5 & Tempe dan tahu & 54,92 & $-134,57$ & $\begin{array}{c}1,06 \\
(1,46) \\
\end{array}$ & $\begin{array}{l}-0,42 \\
(-0,75) \\
\end{array}$ & $\begin{array}{c}34,97 \\
(2,19)^{* *}\end{array}$ & 0,79 & 3,81 \\
\hline 6 & Kerupuk & 132,99 & 147,13 & $\begin{array}{c}0,98 \\
(1,87)^{*}\end{array}$ & $\begin{array}{l}-0,96 \\
(-0,97) \\
\end{array}$ & $\begin{array}{c}-0,41 \\
(-0,46)\end{array}$ & 0,61 & 1,18 \\
\hline 7 & $\begin{array}{l}\text { Makanan dari } \\
\text { kacang }\end{array}$ & 103,95 & 68,79 & $\begin{array}{c}0,76 \\
(1,10)\end{array}$ & $\begin{array}{c}3,37 \\
(3,57)^{* * *}\end{array}$ & $\begin{array}{l}-11,16 \\
(-2,07)^{*}\end{array}$ & 0,90 & $8,58 * *$ \\
\hline 8 & $\begin{array}{l}\text { Pertenunan } \\
\text { ATBM }\end{array}$ & 64,65 & $-103,15$ & $\begin{array}{l}-3,85 \\
(-1,22) \\
\end{array}$ & $\begin{array}{c}0,60 \\
(1,46)\end{array}$ & $\begin{array}{c}0,02 \\
(4,88)^{* * *}\end{array}$ & 0,83 & $16,30 * * *$ \\
\hline 9 & $\begin{array}{l}\text { M oulding dan } \\
\text { komponen bahan } \\
\text { bangunan }\end{array}$ & 412,13 & 259 & $\begin{array}{c}5,76 \\
(1,48)\end{array}$ & $\begin{array}{l}-9,94 \\
(-1,49)\end{array}$ & $\begin{array}{l}45,33 \\
(1,53)\end{array}$ & 0,74 & 2,43 \\
\hline 10 & $\begin{array}{l}\text { Perabot/ } \\
\text { perlengkapan RT }\end{array}$ & 108,70 & 19,97 & $\begin{array}{c}0,02 \\
(5,53)^{* * *} \\
\end{array}$ & $\begin{array}{c}-1,20 \\
(-4,00)^{* * *} \\
\end{array}$ & $\begin{array}{l}-0,56 \\
(-0,63) \\
\end{array}$ & 0,95 & $48,78^{* * *}$ \\
\hline 11 & $\begin{array}{l}\text { Percetakan dan } \\
\text { penerbitan }\end{array}$ & 415,55 & 211,02 & $\begin{array}{c}0,01 \\
(2,52)^{* *} \\
\end{array}$ & $\begin{array}{l}0,002 \\
(0,13) \\
\end{array}$ & $\begin{array}{c}6,65 \\
(1,62) \\
\end{array}$ & 0,62 & $5,32 * * *$ \\
\hline 12 & J asa foto copy & 65,49 & 15,76 & $\begin{array}{c}0,01 \\
(1,39) \\
\end{array}$ & $\begin{array}{c}0,06 \\
(1,44) \\
\end{array}$ & $\begin{array}{c}3,44 \\
(3,07)^{* * *} \\
\end{array}$ & 0,74 & $10,25^{* * *}$ \\
\hline 13 & Kosmetika/ salon & 48,76 & 30,11 & $\begin{array}{l}0,001 \\
(0,14) \\
\end{array}$ & $\begin{array}{c}0,70 \\
(2.62)^{* *} \\
\end{array}$ & $\begin{array}{c}-1,97 \\
(-1,92)^{*} \\
\end{array}$ & 0,70 & $3,61^{* *}$ \\
\hline 14 & Bahan kimia & 171,97 & 64,40 & $\begin{array}{c}0,22 \\
(2,42)^{*}\end{array}$ & $\begin{array}{c}1,10 \\
(2,49)^{*}\end{array}$ & $\begin{array}{c}-2,83 \\
(-1,08) \\
\end{array}$ & 0,99 & $149,24^{* * *}$ \\
\hline
\end{tabular}


Tabel 3 (lanjutan)

\begin{tabular}{|c|c|c|c|c|c|c|c|c|}
\hline 15 & $\begin{array}{l}\text { Vulkanisir dan } \\
\text { tempel ban }\end{array}$ & 85,07 & $-21,15$ & $\begin{array}{l}-0,01 \\
(0,62)\end{array}$ & $\begin{array}{c}1,28 \\
(3,36)^{* * *}\end{array}$ & $\begin{array}{c}12,33 \\
(2,14)^{*}\end{array}$ & 0,97 & $41,25 * * *$ \\
\hline 16 & Kemasan plastik & 252,82 & 94,95 & $\begin{array}{c}0,85 \\
(0,69)\end{array}$ & $\begin{array}{c}0,78 \\
(1,53)\end{array}$ & $\begin{array}{l}-6,68 \\
(-0,88)\end{array}$ & 0,93 & $8,01^{*}$ \\
\hline 17 & $\begin{array}{l}\text { Pembuatan profil } \\
\text { dengan las }\end{array}$ & 84,82 & 54,45 & $\begin{array}{c}0,001 \\
(1,89)^{*}\end{array}$ & $\begin{array}{l}0,006 \\
(0,04)\end{array}$ & $\begin{array}{c}2,24 \\
(2,88)^{* *}\end{array}$ & 0,75 & 2,93 \\
\hline 18 & $\begin{array}{l}\text { Perbaikan motor } \\
\text { mula }\end{array}$ & 91,60 & $-16,18$ & $\begin{array}{c}0,09 \\
(1,57)\end{array}$ & $\begin{array}{c}0,88 \\
(5,77)^{*}\end{array}$ & $\begin{array}{c}6,43 \\
(10,71)^{* * *}\end{array}$ & 0,99 & $235,17 * * *$ \\
\hline 19 & $\begin{array}{l}\text { Komponen } \\
\text { mesin \& suku } \\
\text { cadang }\end{array}$ & 97,25 & 41,58 & $\begin{array}{l}-0,004 \\
(-0.34)\end{array}$ & $\begin{array}{c}0,075 \\
(5,77)^{* * *}\end{array}$ & $\begin{array}{c}5,01 \\
(10,71)^{* * *}\end{array}$ & 0,73 & $3,02 *$ \\
\hline 20 & $\begin{array}{l}\text { Barang perhiasan } \\
\text { dari logam }\end{array}$ & 83,85 & 76,16 & $\begin{array}{l}0,002 \\
(0,31) \\
\end{array}$ & $\begin{array}{l}0,087 \\
(0,97) \\
\end{array}$ & $\begin{array}{c}0,18 \\
(0,30)\end{array}$ & 0,37 & 0,49 \\
\hline 21 & $\begin{array}{l}\text { Perlengkapan } \\
\text { sepeda dan beca }\end{array}$ & 33,15 & 2,00 & $\begin{array}{c}0,023 \\
(4,11)^{* *}\end{array}$ & $\begin{array}{c}0,031 \\
(7,38)^{* *}\end{array}$ & $\begin{array}{l}-0,19 \\
(-0.89) \\
\end{array}$ & 0,99 & $42.45 *$ \\
\hline
\end{tabular}

Sumber: Dinas Perindag Kota Pematangsiantar (diolah)

Keterangan:

(1) Angka dalam kurung (...) adalah t-hitung

(2) $*: \alpha=10 \%, * *: \alpha=5 \%, * * *: \alpha=1 \%$

(3) Nilai produksi dalam jutaan rupiah

Berdasarkan Tabel 3 dapat dibuat urutan jenis industri kecil berpotensi berdasarkan nilai produksi. Selanjutnya, prospek pengembangannya dilihat dari koefisien regresi dari masing-masing variabel, yaitu kapasitas produksi, nilai investasi, dan jumlah tenaga kerja. J enis industri kecil berpotensi dan pengembangan masing-masing jenis industri yang dapat memiliki prospek yang baik disajikan pada Tabel 4.

Tabel 4. J enis Industri Berpotensi dan U paya Pengembangannya

\begin{tabular}{|l|l|}
\hline J enis Industri & Upaya Pengembangan Melalui Peningkatan: \\
\hline percetakan dan penerbitan & kapasitas produksi dan modal kerja \\
\hline moulding dan komponen bahan bangunan & efisiensi penggunaan modal kerja \\
\hline pengolahan teh & modal kerja \\
\hline kemasan dari plastik & kapasitas produksi dan modal kerja \\
\hline bahan kimia & kapasitas produksi dan modal kerja \\
\hline pengolahan/ pengawetan ikan & kapasitas produksi dan modal kerja \\
\hline kerupuk & efisiensi penggunaan faktor produksi \\
\hline perabot/ perlengkapan rumah tangga & kapasitas produksi dan keterampilan tenaga kerja \\
\hline makanan dari kacang & modal keria \\
\hline pengolahan kopi & jumlah tenaga kerja \\
\hline komponen mesin dan suku cadang & modal kerja dan tenaga kerja \\
\hline perbaikan motor mula & modal kerja dan tenaga kerja \\
\hline vulkanisir dan tempel ban & modal kerja dan tenaga kerja \\
\hline pembuatan profil dengan las & kapasitas produksi dan tenaga kerja \\
\hline
\end{tabular}


Tabel 4 (lanjutan)

\begin{tabular}{|l|l|}
\hline perhiasan dari logam & -- \\
\hline jasa foto copy & jumlah tenaga kerja \\
\hline pertenunan ATBM & modal kerja, jumlah dan keterampilan tenaga kerja \\
\hline roti & modal kerja \\
\hline kosmetika/ salon & modal kerja \\
\hline tempe dan tahu & jumlah tenaga kerja \\
\hline perlengkapan sepeda dan beca & kapasitas produksi dan modal kerja \\
\hline
\end{tabular}

\section{KESIMPULAN DAN SARAN}

\subsection{Kesimpulan}

a. Peranan perekonomian Kota Pematangsiantar dalam perekonomian Sumatera Utara tidak terlalu besar pada empat lapangan usaha, yaitu (a) Industri pengolahan, (b) perdagangan, hotel dan restoran, (c) pengangkutan dan komunikasi, serta (d) jasa-jasa. Kontribusi terbesar diberikan subsektor industri kecil dan rumah tangga, mencapai 7,19\%, sedangkan industri besar dan sedang hanya $4,72 \%$.

b. Berdasarkan nilai produksi, jenis industri kecil berpotensi adalah: (1) percetakan dan penerbitan, (2) moulding dan komponen bahan hangunan, (3) pengolahan teh, (4) kemasan plastik, (5) bahan kimia, (6) pengolahan/ pengawetan ikan, (7) kerupuk, (8) perabot/ perlengkapan rumah tangga, (9) makanan dari kacang, (10) pengolahan kopi, (11) komponen mesin dan suku cadang, (12) perbaikan motor mula, (13) vulkanisir dan tempel ban, (14) pembuatan profil dengan las, (15) perhiasan dari logam, (16) jasa foto copy, (17) pertenunan ATBM, (18) roti, (19) koimetika/ salon, (20) tempe dan tahu, dan (21) perlengkapan sepeda dan becak.

c. Secara umum, pengembangan berbagai jenis industri kecil tersebut dapat memiliki prospek yang baik melalui upaya-upaya peningkatan kapasitas produksi, peningkatan modal kerja/ investasi, serta peningkatan jumlah dan keterampilan tenaga kerja.

\subsection{Saran}

a. Pada dasarnya, semua jenis industri kecil dapat berkembang pada suatu wilayah. Namun demikian, pemerintah seyogianya mempunyai kebijakan yang fokus untuk mengarahkan pengembangan beberapa jenis industri kecil yang memiliki potensi dan prospek bagi perkembangan ekonomi kota. Pengembangan industri kecil sebaiknya dilakukan dengan kombinasi variabel nilai produksi dan tenaga kerja.

b. Kebijakan pengembangan produk harus diikuti oleh pengembangan pasar dan promosi. Salah satu alternatif yang dapat dilakukan untuk itu adalah dengan mengembangkan suatu pusat promosi produk industri kecil dan pariwisata.

\section{DAFTAR PUSTAKA}

Badan Pusat Statistik Kota Pematangsiantar dan Bappeda Kota Pematangsiantar. 1988. PDRB Kota Pematangsiantar 1993-2001. 
Badan Pusat Statistik Sumatera Utara. 2001. Produk Domestik Regional Bruto Sumatera Utara 1994-2000.

Biro Humas Departemen Perindustrian. 1984. Undang-Undang Republik Indonesia Nomor 5 Tahun 1984 tentang Perindutrian.

Blakely, Edward J. 1994. Planning Local Economic Development, Theory and Practice. Sage Publication. California.

Dinas Perindustrian dan Perdagangan Kota Pematangsiantar. 2002. Daftar Perusahaan Industri dan Dagang di Kota Pematangsiantar Tahun 2001.

Renstra Pemerintah Kota Pematangsiantar Tahun 2001 -2005.

Sirait, K. Tunggul. 1994. Kata Sambutan pada Seminar Sehari Peranan Strategis Industri Kecil dalam PJ P-II, Lembaga Penelitian Universitas Kristen Indonesia, J akarta.

Swasono, Sri-Edi. 1994. Pengembangan Industri Kecil sebagai Gerakan Ekonomi Rakyat dalam Prosiding Seminar Nasional Sehari "Peranan Strategis Industri Kecil dalam PJ P-II", Lembaga Penelitian Universitas Kristen Indonesia, J akarta.

Subiakto. 1994. Pidato dan Pengarahan Menteri Koperasi dan PPK pada Seminar Sehari "Peranan Strategis Industri Kecil dalam PJ P-II", Lembaga Penelitian Universitas Kristen Indonesia, J akarta.

Tambunan, Tulus. 1994. Peranan Industri Skala Kecil dalam Meningkatkan Nilai Tambah Ekonomi di Pedesaan dalam Prosiding Seminar Nasional Sehari "Peranan Strategis Industri Kecil dalam PJ P-II", Lembaga Penelitian Universitas Kristen Indonesia, J akarta. 